\title{
MORFOLOŠKE ZNAČAJKE KONTEJNERSKIH SADNICA HRASTA LUŽNJAKA (Quercus robur L.) IZ SJEMENSKE REGIJE GORNJA POSAVINA I POKUPLJE (1.2.3.)
}

\section{MORPHOLOGICAL PROPERTIES OF CONTAINER SEEDLINGS OF PEDUNCULATE OAK (Quercus robur L.) FROM THE SEED REGION OF GORNJA POSAVINA AND POKUPLJE (1.2.3.)}

\author{
Sandra CRNKOVIĆ ${ }^{1}$, Damir DRVODELIĆ2, Sanja PERIĆ3
}

\begin{abstract}
SAŽETAK
Šume uređajnog razreda hrasta lužnjaka (Quercus robur L.) u Republici Hrvatskoj prostiru se na površini od oko 200.000 ha. S obzirom na veličinu areala, ukupnu drvnu zalihu koja iznosi više od 48 mil. m³ , godišnji tečajni prirast od 1 mil. $\mathrm{m}^{3}$ i morfološku izdiferenciranost, proučavanje lužnjakovih provenijencija od velike je važnosti. Klonske sjemenske plantaže osnovane su s ciljem učestalog uroda, dobivanja genetski kvalitetnog sjemenskog materijala i očuvanje genetske raznolikosti koja smanjuje mogućnost nestanka lokalnih populacija uslijed promijenjenih okolišnih uvjeta ili pojave novih bolesti i štetnika. U klonskoj sjemenskoj plantaži hrasta lužnjaka (Quercus robur L.) „Plešćice“ iz uroda 2015. godine sakupili smo uzorke sjemenskog materijala s ukupno 49 različitih klonova, i u kontroliranim uvjetima uzgojili jednogodišnje sadnice u kontejnerima. Na uzorcima od po 5 sadnica svakog klona izmjerili smo suhu masu lišća, stabljike i korijena, utvrdili morfološke razlike, varijabilnost i definirali klonove čije sadnice imaju slab potencijal za korištenje u biološkoj obnovi šuma. Kod uzoraka šest klonova utvrđena je srednja suha masa korijena manja od 2,0 g, a četiri od njih imaju i nepovoljan omjer suhe mase nadzemnog dijela i suhe mase korijenskog sustava, pa je za pretpostaviti da bi sadnice tih uzoraka imale loš primitak na terenu, slabo preživljenje i inicijalni rast.
\end{abstract}

KLJUČNE RIJEČI: Klonska sjemenska plantaža, šumske sadnice, kontejneri, suha biomasa sadnica, varijabilnost.

UVOD

\section{INTRODUCTION}

Hrast lužnjak (Quercus robur L.) je vrlo važna vrsta u šumarstvu Republike Hrvatske čijom su se problematikom bavile sve generacije naših šumarskih stručnjaka od nastanka šumarske znanosti u Europi do danas (Matić, 1996).

Od svih europskih hrastova ima najveće područje rasprostranjenosti (Sever, 2012), a u Republici Hrvatskoj šume

\footnotetext{
${ }^{1}$ Mr. sc. Sandra Crnković, Hrvatske šume d.o.o., Uprava šuma Podružnica Bjelovar, 43000 Bjelovar, Matošev trg 1, e-mail: sandra.crnkovic@hrsume.hr

${ }^{2}$ Doc. dr. sc. Damir Drvodelić, Šumarski fakultet Sveučilišta u Zagrebu, Zavod za ekologiju i uzgajanje šuma, Svetošimunska cesta 25, 10000 Zagreb, e-mail: ddrvodelic@inet.hr

${ }^{3}$ Doc. dr. sc. Sanja Perić, Hrvatski šumarski institut, Cvjetno naselje 41, 10450 Jastrebarsko, e-mail: sanjap@sumins.hr
} 
uređajnog razreda hrasta lužnjaka prostiru se na površini od oko 200.000 ha (Šumsko gospodarska osnova područja, 2016-2025). S obzirom na veličinu areala i veliku varijabilnost morfoloških i fizioloških karakteristika proučavanje hrasta lužnjaka i njegovih provenijencija ima značajnu ulogu (Perić, 2001).

Uslijed neperiodičnog uroda, prirodna obnova lužnjakovih sastojina, kao najvažniji i najčešći način pomlađivanja, otežana je te ju potpomažemo umjetnom - sadnjom žira pod motiku ili sadnjom sadnica, a ponekad smo prinuđeni kompletno pomlađivanje obaviti umjetnim putem, ne napuštajući načela oplodnih sječa (Matić i dr.,1996).

U počecima gospodarenja šumama, urodu se nije pridavalo veliko značenje, jer su se sastojine redovito obnavljale bez utjecaja čovjeka. Međutim, zbog nepovoljnih ekoloških uvjeta, koji se očituju u promjeni režima vlaženja, padu razina podzemne vode i izostanka poplava uslijed regulacije rijeke Save i pritoka, stabla hrasta lužnjaka fiziološki slabe te se češće na njima pojavljuju štetnici, a sve to uzrokuje sušenje i propadanje hrastika, izostanak uroda i smanjenje kvalitete žira (Saračević, 2002), urod više nije periodičan kao što je bio nekada kada se obično svake pete ili šeste godine pojavio jedan puni urod, a između toga jedan ili dva manja uroda (Vidaković, 1996).

Kako bi se ublažio nedostatak sjemena u godinama bez uroda ili sa slabim i nedostatnim urodom, započelo se s osnivanjem klonskih sjemenskih plantaža (Kajba i dr., 2009). U takvim nasadima može se kontrolirati proizvodnja s obzirom na genetsku kvalitetu i na urod, te se mogu planirati i proizvoditi potrebne količine genetski superiornog žira (Vidaković, 1996). Osim što pridonose očuvanju genetske raznolikosti, održavanje široke genetske baze smanjuje mogućnost nestanka provenijencija u izmijenjenim uvjetima ili zbog njihove osjetljivosti na nove bolesti ili štetnike. Sjemenske plantaže su daleko najvažnija poveznica između operativne šumarske prakse $s$ jedne strane i oplemenjivanja i pratećih znanstvenih istraživanja s druge (Katičić, 2012).

Na području kojim gospodari UŠP Bjelovar odabrana su 53 plus stabla: u gospodarskoj jedinici „Česma“ (klonovi broj $1,8-15,28,41-45,47-49,53)$, „Čazmanske nizinske šume“ (klonovi broj 2-7, 16-19, 46, 50, 52), „Trupinski - Pašijanski gaj“ (klonovi broj 20, 21, 25-27), „Zdenački gaj - Prespinjača“ (klonovi broj 22-24, 37, 38), „Međuvođe - Ilovski lug“ (klonovi broj 29-34, 51), „Daruvarske prigorske šume“ (klonovi broj 35, 36), „Grđevačka Bilogora“ (klonovi broj 39, 40). Cijepljenjem njihovih plemki na dvogodišnje sadnice uzgojene u rasadniku, i sadnjom dobivenih cjepova, osnovana je klonska sjemenska plantaža hrasta lužnjaka „Plešćice“ u Čazmi 2001. godine.

$\mathrm{U}$ šumskim rasadnicima, za potrebe obnove šuma, proizvode se sadnice hrasta lužnjaka golog korijena klasičnom metodom sjetvom žira na izdignutim gredicama (Matić, 1996), a kontejnerska proizvodnja sa svojim prednostima (smanjen šok presadnje te bolje preživljavanje, lakša i brža sadnja, smanjeni troškovi te produljeno vrijeme sadnje) svakako ima prostora za primjenu. Kontejnerski proizvedene sadnice imaju bolji početni rast i veću vitalnost, a visoko preživljavanje biljaka sađenih do 13.7. dobar je pokazatelj da se dosadašnje vrijeme sadnje može produžiti do polovice sedmog mjeseca, a rezultati će biti zadovoljavajući (Oršanić i dr., 1996).

Ciljevi ovoga rada:

1. Utvrditi morfološke razlike (masa biljaka nakon sušenja) sadnica hrasta lužnjaka uzgojenih od žira sakupljenog u klonskoj sjemenskoj plantaži „Plešćice“iz uroda 2015. godine

2. Utvrditi varijabilnost mase biljaka nakon sušenja

3. Definirati klonove čiji šumski reprodukcijski materijal ima slab potencijal u smislu korištenja za prirodnu obnovu nizinskih šumskih ekosustava hrasta lužnjaka u sjemenskoj regiji 1.2.3.

\section{MATERIJAL I METODE MATERIAL AND METHODS}

U klonskoj sjemenskoj plantaži hrasta lužnjaka „Plešćice“, $\left(16^{\circ} 35^{\prime} 08^{\prime \prime}\right.$ istočne geografske dužine i $45^{\circ} 45^{\prime} 00^{\prime \prime}$ sjeverne geografske širine.), koja je osnovana 2001. godine na području UŠP Bjelovar, šumarije Čazma, sakupili smo u jesen 2015. godine uzorke žira s ukupno 49 klonova.

Kontejnere tipa HIKO V530 (dimenzije kontejnera $352 \times 216 \times 200 \mathrm{~mm}, 15$ otvora, volumen jednog otvora $530 \mathrm{ml}$ ) napunili smo supstratom (proizvođač Dupreta, supstrat proizveden od ekološki čistog treseta, osnovni sastojak su mahovine roda Sphagnum H3-H7, količina organskog materijala: 92-96 \%; kiselost $\mathrm{pH}(\mathrm{CaCl}) 5,2-6,0$; električna provodljivost $0,9-1,5 \mathrm{mS} / \mathrm{cm}$ ). U svaki otvor multikontejnera, posijali smo po 2 žira i prekrili ih supstratom do $2 \mathrm{~cm}$ debljine. Svaki lončić zalili s po $1 \mathrm{dcl}$ vode (do momenta otjecanja vode kroz drenažne otvore).

Kontejnere smo smjestili u komoru rasta Kambič, RK-980 $\mathrm{CH}$, u laboratoriju za šumsko sjemenarstvo i rasadničarstvo Šumarskog fakulteta Sveučilišta u Zagrebu i definirali u njoj uvjete: konstantna temperatura od $20^{\circ} \mathrm{C}$, zračna vlaga $80 \%$, osvjetljenje od 13400 lux-a (na površini multikontejnera) do 14000 luxa (ispod samih lampi) tijekom 12 sati dnevno (mjereno pomoću lux metra model LX-101 LUX METER Lutron). Uzgojem biljaka u kontroliranim uvjetima varijabilnost okolišnih čimbenika možemo svesti na minimum (Hanson, 1986).

U idućem razdoblju od 63 dana, svakih sedam dana zalijevali smo svaki otvor multikontejnera s količinom od $0,5 \mathrm{dcl}$ 
Tablica 1. Deskriptivna statistika temperature zraka, relativne zračne vlage i točke rosišta u stakleniku

Table 1 Descriptive statistics of air temperature, relative air humidity and dew point in the greenhouse

\begin{tabular}{|c|c|c|c|}
\hline & Temperatura ${ }^{\circ} \mathrm{C}$ & $\begin{array}{l}\text { Relativna zračna } \\
\text { vlaga (\%) }\end{array}$ & Točka rosišta \\
\hline & Temperature ${ }^{\circ} \mathrm{C}$ & $\begin{array}{c}\text { Relative air } \\
\text { humidity (\%) }\end{array}$ & ${ }^{\circ} \mathrm{C}$ \\
\hline Srednja & 21,3 & 70,3 & 15,4 \\
\hline Minimalna & 14,5 & 21,0 & 7,3 \\
\hline Maksimalna & 41,6 & 89,7 & 25,4 \\
\hline St.dev. & 3,8889578 & 9,972243 & 2,656203 \\
\hline
\end{tabular}

vode, a nakon što je žir nabubrio $\mathrm{s} 0,25 \mathrm{dcl}$ vode. Nakon istraživanja u komori rasta, preselili smo kontejnere u staklenik Hrvatskog šumarskog instituta u Jastrebarskom. Uvjeti u stakleniku prikazani su u tablici br. 1.

Izmjere parametara u stakleniku bilježene su svakih $30 \mathrm{mi-}$ nuta.

Ukupno 176 dana od sjetve iz svakog smo kontejnera slučajnim odabirom izdvojili po pet sadnica, te svakoj nakon sušenja na zraku do konstantne mase analitičkom vagom
PRECISA $2200 \mathrm{C}(\max =2250 \mathrm{~g}$, raspon vaganja $200 \mathrm{~g}-1500 \mathrm{~g}$, točnost $=0,01 \mathrm{~g}$ ) utvrdili masu lišća, stabljike i korijena.

Ukupno smo u istraživanju izmjerili parametre 245 biljaka ( 5 biljaka od svakog od 49 klonova).

Statističkom analizom (Statistica 7.1) ispitali smo pripadaju li promatrani uzorci istoj populaciji, odnosno jesu li sredine promatranih svojstava jednake za sve klonove, te je nulta hipoteza od koje polazimo - prosječne srednje vrijednosti svih uzoraka su jednake.

Pri uspoređivanju testirali smo da li je varijabilnost između pojedinih uzoraka veća od varijabilnosti unutar uzoraka ( $\mathrm{tj}$. varijabilnosti koju ne možemo objasniti). Ako je potvrđena - možemo pretpostaviti da se radi o različitim populacijama. Postojanje statistički značajne razlike testirali smo Post Hoc LSD testom.

\section{REZULTATI RESULTS}

U tablici 2 prikazane su srednje vrijednosti analiziranih parametara (biomasa u suhom stanju) po klonovima.

Tablica 2. Srednje vrijednosti mase pojedinih organa kontejnerskih sadnica hrasta lužnjaka (Quercus robur L.) nakon sušenja i omjer suhe mase nadzemnog dijela i korijenskog sustava sadnica po klonovima

Table 2 Mean mass values of individual organs of container seedlings of pedunculate oak (Quercus robur L.) after drying and dry mass ratio of aboveground part and root system per clone

\begin{tabular}{|c|c|c|c|c|c|c|}
\hline \multirow{3}{*}{$\begin{array}{l}\text { KLON } \\
\text { CLONE }\end{array}$} & \multicolumn{5}{|c|}{ MASA SADNICA NAKON SUŠENJA / SEEDLING MASS AFTER DRYING } & \multirow{2}{*}{$\begin{array}{c}\text { OMJER SUHE MASE } \\
\text { NADZEMNI DIO / KORIJEN } \\
\text { DRY MATTER RATIO OF } \\
\text { ABOVE-GROUND PART / ROOT }\end{array}$} \\
\hline & $\begin{array}{l}\text { LIŠĆE } \\
\text { LEAVES }\end{array}$ & $\begin{array}{l}\text { STABLJIKA } \\
\text { STEMS }\end{array}$ & $\begin{array}{c}\text { NADZEMNI DIO } \\
\text { ABOVE-GROUND PART }\end{array}$ & $\begin{array}{l}\text { KORIJEN } \\
\text { ROOT }\end{array}$ & $\begin{array}{l}\text { UKUPNO } \\
\text { TOTAL }\end{array}$ & \\
\hline & $\mathrm{g}$ & $\mathrm{g}$ & $\mathrm{g}$ & $\mathrm{g}$ & $\mathrm{g}$ & \\
\hline 1 & 0,45 & 0,43 & 0,88 & 2,84 & 3,72 & 0,31 \\
\hline 2 & 0,39 & 0,22 & 0,61 & 2,62 & 3,23 & 0,23 \\
\hline 3 & 0,37 & 0,23 & 0,61 & 1,97 & 2,58 & 0,31 \\
\hline 4 & 0,48 & 0,39 & 0,87 & 3,81 & 4,69 & 0,23 \\
\hline 5 & 0,39 & 0,34 & 0,73 & 2,55 & 3,28 & 0,29 \\
\hline 6 & 0,38 & 0,26 & 0,65 & 2,40 & 3,05 & 0,27 \\
\hline 7 & 0,51 & 0,31 & 0,82 & 2,56 & 3,38 & 0,32 \\
\hline 8 & 0,50 & 0,38 & 0,88 & 4,10 & 4,98 & 0,22 \\
\hline 9 & 0,50 & 0,41 & 0,91 & 2,98 & 3,89 & 0,31 \\
\hline 11 & 0,32 & 0,27 & 0,60 & 2,41 & 3,00 & 0,25 \\
\hline 12 & 0,36 & 0,21 & 0,57 & 3,27 & 3,84 & 0,18 \\
\hline 13 & 0,36 & 0,33 & 0,69 & 2,12 & 2,81 & 0,33 \\
\hline 14 & 0,35 & 0,30 & 0,66 & 2,42 & 3,08 & 0,27 \\
\hline 15 & 0,33 & 0,29 & 0,62 & 2,26 & 2,88 & 0,27 \\
\hline 16 & 0,77 & 0,52 & 1,29 & 3,53 & 4,82 & 0,36 \\
\hline 17 & 0,31 & 0,21 & 0,53 & 2,39 & 2,92 & 0,22 \\
\hline 18 & 0,47 & 0,31 & 0,78 & 2,77 & 3,55 & 0,28 \\
\hline 20 & 0,62 & 0,53 & 1,15 & 2,85 & 4,00 & 0,40 \\
\hline 21 & 0,47 & 0,24 & 0,72 & 1,83 & 2,54 & 0,39 \\
\hline 22 & 0,35 & 0,38 & 0,73 & 2,69 & 3,42 & 0,27 \\
\hline 23 & 0,55 & 0,46 & 1,01 & 3,12 & 4,13 & 0,32 \\
\hline 24 & 0,41 & 0,52 & 0,93 & 2,56 & 3,49 & 0,37 \\
\hline
\end{tabular}




\begin{tabular}{|c|c|c|c|c|c|c|}
\hline 25 & 0,31 & 0,21 & 0,52 & 4,00 & 4,52 & 0,13 \\
\hline 26 & 0,46 & 0,35 & 0,82 & 2,98 & 3,80 & 0,27 \\
\hline 27 & 1,26 & 1,67 & 2,93 & 3,25 & 6,18 & 0,90 \\
\hline 28 & 0,41 & 0,50 & 0,91 & 1,63 & 2,54 & 0,56 \\
\hline 29 & 0,94 & 0,90 & 1,84 & 2,42 & 4,26 & 0,76 \\
\hline 30 & 0,89 & 1,18 & 2,07 & 3,70 & 5,77 & 0,56 \\
\hline 31 & 0,61 & 0,53 & 1,14 & 1,74 & 2,88 & 0,65 \\
\hline 32 & 1,17 & 1,13 & 2,29 & 3,80 & 6,09 & 0,60 \\
\hline 33 & 0,79 & 0,72 & 1,51 & 2,54 & 4,04 & 0,59 \\
\hline 34 & 0,93 & 0,99 & 1,92 & 3,10 & 5,03 & 0,62 \\
\hline 36 & 0,80 & 0,51 & 1,31 & 2,05 & 3,36 & 0,64 \\
\hline 37 & 0,80 & 0,82 & 1,61 & 3,34 & 4,96 & 0,48 \\
\hline 38 & 0,72 & 0,62 & 1,34 & 2,88 & 4,22 & 0,47 \\
\hline 39 & 1,01 & 0,97 & 1,97 & 2,85 & 4,82 & 0,69 \\
\hline 40 & 0,64 & 0,79 & 1,43 & 2,80 & 4,23 & 0,51 \\
\hline 41 & 1,02 & 1,18 & 2,20 & 3,08 & 5,28 & 0,71 \\
\hline 42 & 0,69 & 0,83 & 1,52 & 2,50 & 4,02 & 0,61 \\
\hline 43 & 0,54 & 0,44 & 0,98 & 2,10 & 3,08 & 0,47 \\
\hline 44 & 0,97 & 1,03 & 2,00 & 3,52 & 5,52 & 0,57 \\
\hline 45 & 0,99 & 1,12 & 2,11 & 3,69 & 5,79 & 0,57 \\
\hline 46 & 0,70 & 0,91 & 1,61 & 3,48 & 5,08 & 0,46 \\
\hline 47 & 0,90 & 0,94 & 1,84 & 3,11 & 4,95 & 0,59 \\
\hline 48 & 0,56 & 0,62 & 1,18 & 2,63 & 3,80 & 0,45 \\
\hline 49 & 0,78 & 1,02 & 1,80 & 3,11 & 4,91 & 0,58 \\
\hline 51 & 0,56 & 0,70 & 1,26 & 1,98 & 3,24 & 0,64 \\
\hline 52 & 0,65 & 0,76 & 1,41 & 3,07 & 4,47 & 0,46 \\
\hline 53 & 1,14 & 1,02 & 2,16 & 1,95 & 4,11 & 1,11 \\
\hline
\end{tabular}

ANOV-om je utvrđeno da postoji statistički značajna razlika između aritmetičkih sredina uzoraka, te na donjoj granici signifikantnosti ne možemo prihvatiti pretpostavku da uzorci pripadaju istoj populaciji. Za određivanje koji uzorci čine razliku koristili smo LSD test.

Najveću srednju ukupnu biomasu imale su sadnice klona 27 i iznosila je 6,18 g. Najmanju srednju ukupnu biomasu imale su sadnice klonova 21 i 28 i iznosile su 2,54 g. Klon 27 po ovom se parametru statistički razlikuje s 27 ostalih uzoraka.

Tablica 3: Jednofaktorskom analizom varijance utvrđena je statistički značajna razlika u ukupnoj suhoj biomasi kontejnerskih sadnica hrasta lužnjaka (Quercus robur L.) s obzirom na klonove $(\mathrm{F}=1,721, \mathrm{p}=0,00536)$.

Tablica 3. ANOVA za ukupnu suhu biomasu kontejnerskih sadnica hrasta lužnjaka (Quercus robur L.) po klonovima

Table 3 ANOVA for total dry biomass of container seedlings of pedunculate oak (Quercus robur L.) per clone

$\begin{array}{lccccc}\text { Effect } & \text { SS } & \begin{array}{c}\text { Degrees of } \\ \text { Freedom }\end{array} & \text { MS } & \text { F } & p \\ \text { Intercept } & 4010,436 & 1 & 4010,436 & 1436,434 & 0,000000 \\ \text { Klon / Clone } & 230,674 & 48 & 4,806 & 1,721 & 0,005368 \\ \text { Error } & 547,220 & 196 & 2,792 & & \end{array}$

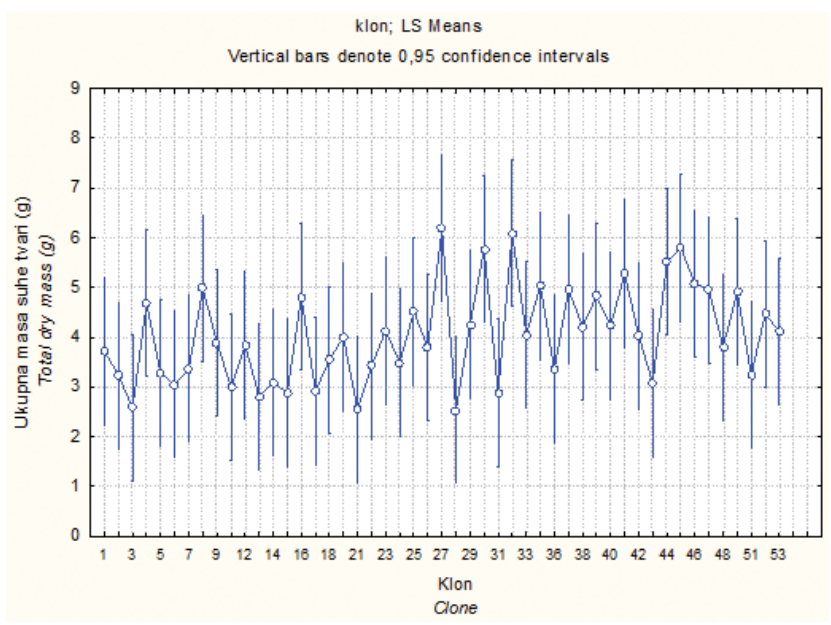

Slika 1. Ukupna masa suhe tvari kontejnerskih sadnica hrasta lužnjaka (Quercus robur L.) po klonovima

*Točke pokazuju srednje vrijednosti a vertikalne linije $95 \%$ pouzdanosti Figure 1 Total dry matter mass of container seedlings of pedunculate oak (Quercus robur L.) per clone

*Points denote mean values and vertical bars denote $95 \%$ confidence values

Sadnice klona 27, koje su imale najveću srednju vrijednost mase nadzemnog dijela $(2,93 \mathrm{~g})$ pokazuju statistički značajnu razliku s ukupno 38 drugih uzoraka. Najmanju srednju vrijednost mase nadzemnog dijela imale su sadnice klona 25 i iznosila je $0,52 \mathrm{~g}$. 
Tablica 4. ANOVA za suhu biomasu nadzemnog dijela kontejnerskih sadnica hrasta lužnjaka (Quercus robur L.) po klonovima

Table 4 ANOVA for dry biomass of above-ground part of container seedlings of pedunculate oak (Quercus robur L.) per clone

$\begin{array}{lccccc}\text { Effect } & \text { SS } & \begin{array}{c}\text { Degrees of } \\ \text { Freedom }\end{array} & \text { MS } & F & p \\ \text { Intercept } & 378,5246 & 1 & 378,5246 & 478,4208 & 0,000000 \\ \text { Klon / Clone } & 82,8193 & 48 & 1,7254 & 2,1808 & 0,000101 \\ \text { Error } & 155,0744 & 196 & 0,7912 & & \end{array}$

Tablica 4: Jednofaktorskom analizom varijance utvrđena je statistički značajna razlika u suhoj biomasi nadzemnog dijela kontejnerskih sadnica hrasta lužnjaka (Quercus robur L.) s obzirom na klonove ( $\mathrm{F}=2,1808, \mathrm{p}=0,000101)$.

Najveću srednju vrijednost biomase lišća imale su sadnice klona 27 i iznosila je 1,26 g. Najmanju srednju vrijednost biomase lišća imale su sadnice klonova 17 i 25 i iznosile su 0,31 g. Sadnice klonova 27, 32 i 53 koje imaju najveću masu lišća pokazuju signifikantnu razliku u testiranju sredina s najviše ostalih uzoraka (razlikuju se s ukupno 33, 30 odnosno 28 drugih uzoraka).

Tablica 5: Jednofaktorskom analizom varijance utvrđena je statistički značajna razlika u suhoj biomasi lišća kontejnerskih sadnica hrasta lužnjaka (Quercus robur L.) s obzirom na klonove $(\mathrm{F}=1,9643, \mathrm{p}=0,00069)$.

Najveću srednju vrijednost biomase stabljike imale su sadnice klonova 27 (1,67 g), 30 (1,18 g) i 41 (1,18 g), pokazuju signifikantnu razliku s najviše ostalih uzoraka (sadnice klona 27 s ukupno 44 , sadnice klonova 30 i 41 s ukupno 28 drugih klonova). Najmanje srednje vrijednosti biomase

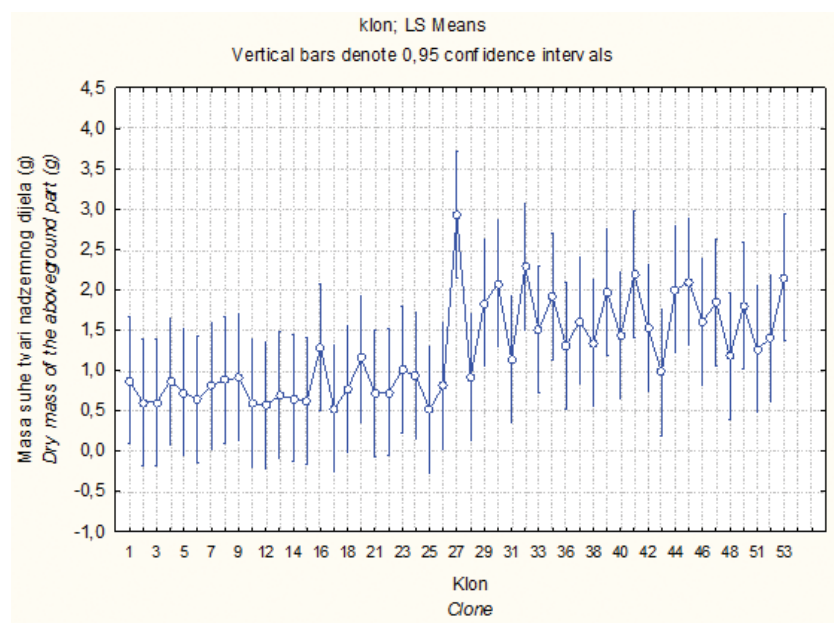

Slika 2. Ukupna masa suhe tvari nadzemnog dijela kontejnerskih sadnica hrasta lužnjaka (Quercus robur L.) po klonovima

*Točke pokazuju srednje vrijednosti a vertikalne linije $95 \%$ pouzdanosti Figure 2 Total dry matter mass of above-ground part of container seedlings of pedunculate oak (Quercus robur L.) per clone

* Points denote mean values and vertical bars denote $95 \%$ confidence values
Tablica 5. ANOVA za suhu biomasu lišća kontejnerskih sadnica hrasta lužnjaka (Quercus robur L.) po klonovima

Table 5 ANOVA for leaf dry biomass of container seedlings of pedunculate oak (Quercus robur L.) per clone

$\begin{array}{lccccc}\text { Effect } & \text { SS } & \begin{array}{c}\text { Degrees of } \\ \text { Freedom }\end{array} & \text { MS } & \text { F } & p \\ \text { Intercept } & 97,45482 & 1 & 97,45482 & 577,3732 & 0,000000 \\ \text { Klon/Clone } & 15,91434 & 48 & 0,33155 & 1,9643 & 0,000696 \\ \text { Error } & 33,08284 & 196 & 0,16879 & & \end{array}$

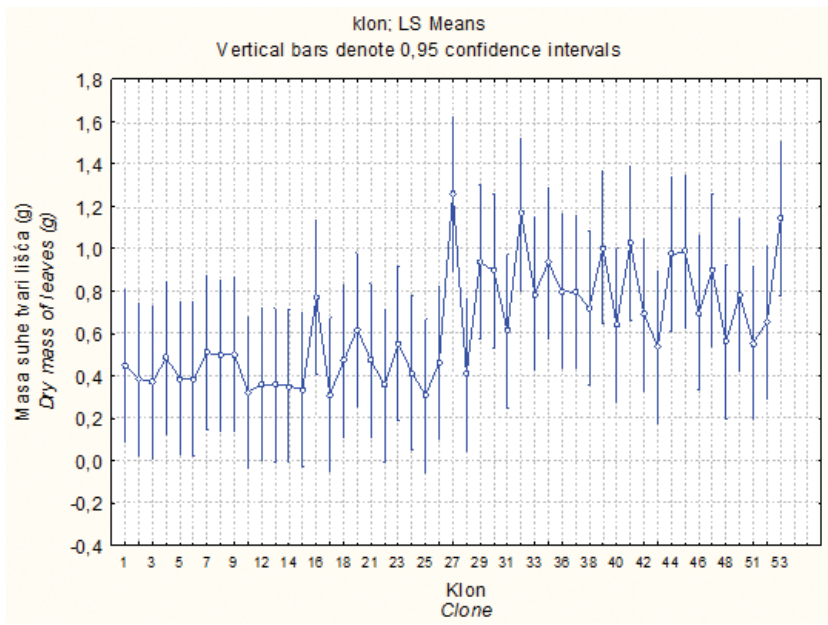

Slika 3. Ukupna masa suhe tvari lišća kontejnerskih sadnica hrasta lužnjaka (Quercus robur L.) po klonovima

*Točke pokazuju srednje vrijednosti a vertikalne linije $95 \%$ pouzdanosti

Figure 3 Total leaf dry mass of container seedlings of pedunculate oak ( $\mathrm{Ou}$ ercus robur L.) per clone

*Points denote mean values and vertical bars denote $95 \%$ confidence values

stabljike imale su sadnice klonova 12, 17 i 25 i iznosile su $0,21 \mathrm{~g}$.

Tablica 6: Jednofaktorskom analizom varijance utvrđena je statistički značajna razlika u suhoj biomasi stabljike kontejnerskih sadnica hrasta lužnjaka (Quercus robur L.) s obzirom na klonove $(\mathrm{F}=2,2711, \mathrm{p}=0,000044)$.

Najveću srednju masu korijena imale su sadnice klonova 8 $(4,10 \mathrm{~g})$ i $25(4,00 \mathrm{~g})$ te pokazuju statistički značajnu razliku s 24 , odnosno 22 ostala uzorka, dok sadnice klona 28 , s najmanjom srednjom masom korijena (1,63 g), pokazuju statistički značajnu razliku s ostalih 20 uzoraka.

Tablica 6. ANOVA za suhu biomasu stabljike kontejnerskih sadnica hrasta lužnjaka (Quercus robur L.) po klonovima

Table 6 ANOVA for stem dry biomass of container seedlings of pedunculate oak (Quercus robur L.) per clone

$\begin{array}{lccccc}\text { Effect } & \text { SS } & \begin{array}{c}\text { Degrees of } \\ \text { Freedom }\end{array} & \text { MS } & \text { F } & p \\ \text { Intercept } & 91,84898 & 1 & 91,84898 & 358,3879 & 0,000000 \\ \text { Klon / Clone } & 27,93832 & 48 & 0,58205 & 2,2711 & 0,000044 \\ \text { Error } & 50,23160 & 196 & 0,25628 & & \end{array}$




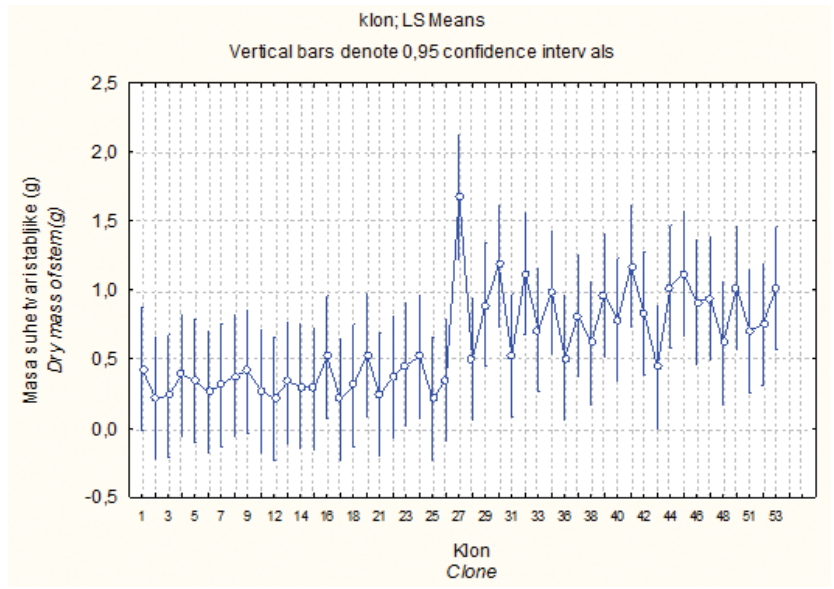

Slika 4. Ukupna masa suhe tvari stabljike kontejnerskih sadnica hrasta lužnjaka (Quercus robur L.) po klonovima

*Točke pokazuju srednje vrijednosti a vertikalne linije 95 \% pouzdanosti

Figure 4 Total stem dry matter of container seedlings of pedunculate oak (Quercus robur L.) per clone

*Points denote mean values and vertical bars denote $95 \%$ confidence values

Tablica 7. ANOVA za suhu biomasu korijenskog sustava kontejnerskih sadnica hrasta lužnjaka (Quercus robur L.) po klonovima

Table 7 ANOVA for root dry biomass of container seedlings of pedunculate oak (Quercus robur L.) per clone

$\begin{array}{lccccc}\text { Effect } & \text { SS } & \begin{array}{c}\text { Degrees of } \\ \text { Freedom }\end{array} & \text { MS } & \text { F } & p \\ \text { Intercept } & 1924,778 & 1 & 1924,778 & 1714,025 & 0,000000 \\ \text { Klon / Clone } & 90,524 & 48 & 1,886 & 1,679 & 0,007501 \\ \text { Error } & 220,100 & 196 & 1,123 & & \end{array}$

Tablica 7: Jednofaktorskom analizom varijance utvrđena je statistički značajna razlika u suhoj biomasi korijenskog sustava kontejnerskih sadnica hrasta lužnjaka (Quercus robur L.) s obzirom na klonove ( $\mathrm{F}=1,679, \mathrm{p}=0,00750)$.

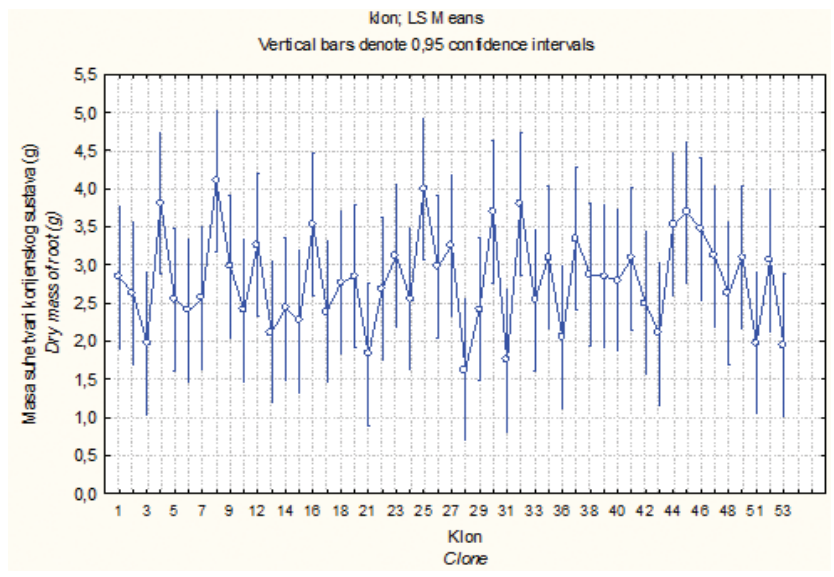

Slika 5. Ukupna masa suhe tvari korijenskog sustava kontejnerskih sadnica hrasta lužnjaka (Quercus robur L.) po klonovima

*Točke pokazuju srednje vrijednosti a vertikalne linije $95 \%$ pouzdanosti Figure 5 Total root dry mass of container seedlings of pedunculate oak ( $\mathrm{Qu}$ ercus robur L.) per clone

*Points denote mean values and vertical bars denote $95 \%$ confidence values
Najveći srednji omjer suhe mase nadzemnog dijela sadnice i korijena imale su sadnice klona 53 i iznosio je 1,11, a najmanji sadnice klona 25 i iznosio je 0,13 .

\section{RASPRAVA DISCUSSION}

Kvaliteta sadnica podrazumijeva sposobnost opstanka i rasta sadnice nakon presadnje i može se ocijeniti prema dobi, morfološkim i fiziološkim značajkama (M. L. Duryea, 1984), a u izravnoj je vezi s genetskim karakteristikama, veličinom, vitalnošću, uvjetima okoline prilikom presađivanja i načinom uzgoja sadnica (Bobinec - Mikek, 2009). Kvalitetna sadnica će, osim uspješnog rasta nakon presadnje, bolje podnijeti transport, skladištenje i rukovanje (Drvodelić i dr., 2013).

Morfološke značajke sadnica su sve fizičke ili vizualno uočljive karakteristike sadnica koje mogu biti opažane ili izmjerene (Ritchie, G. A., 1984). Za određivanje kvalitete sadnica u praksi se koriste visina sadnice i promjer vrata korijena. $U$ znanstvenim istraživanjima određuje se biomasa i omjer suhe mase nadzemnog dijela i korijenskog sustava. Budući da sadržaj vode u tkivu može jako varirati, bolji su podaci dobiveni izmjerom suhe mase nego svježe (Haase, D. L., 2007). U našem istraživanju mjerili smo suhu biomasu sadnica.

Sadnice hrasta lužnjaka (Quercus robur L.) uzgojili smo u kontroliranim uvjetima i time uklonili okolišne čimbenike kao izvor varijabiliteta. Širok raspon dobivenih podataka uvjetovan je podrijetlom sjemenskog materijala. $U$ većini slučajeva sadnice klonova koji potječu iz istih gospodarskih jedinica, tj. s manjeg područja, pokazuju i homogenije podatke za mjerene varijable.

Suha masa jednogodišnjih biljaka hrasta lužnjaka (Quercus robur L.) u različitim tipovima kontejnera iznosi od $4,95 \mathrm{~g}$ do $19,89 \mathrm{~g}$, a u kontejnerima tipa HIKO V530 od 10,75 g do 13,30 g (Orešković i dr., 2006). Podaci dobiveni u našem istraživanju su nižih vrijednosti, i pretpostavljamo da je jedan od uzroka uzgoj po dvije sadnice u jednom otvoru kontejnera, budući da veličina kontejnera pozitivno utječe na produkciju biomase (Ocvirek, 1997).

Masa nadzemnog dijela sadnica u našem istraživanju pokazuje veću varijabilnost, dok su podaci za klonove koji potječu iz istih gospodarskih jedinica homogeniji. U istraživanju u kojem je korišten sjemenski materijal iz jednog šumskog sjemenskog objekta suha tvar nadzemnog dijela lužnjakovih sadnica starosti $1+0$ iznosi od 1,5 do $1,9 \mathrm{~g}$ (Brekalo, 2005).

Suha tvar nadzemnog dijela jednogodišnjih biljaka hrasta lužnjaka (Quercus robur L.) uzgojenih u različitm tipovima kontejnera iznosi od 2,48 g do 6,61 g, a u kontejneru tipa HIKO V530 od 4,22 g do 4,47 g (Orešković i dr., 2006). Manje vrijednosti mase nadzemnog dijela sadnica u našem istraživanju dijelom su uzrokovane načinom uzgoja, tj. sjetvom po dva žira u jednom otvoru multikontejnera. 
Suha tvar nadzemnog dijela dvogodišnjih sadnica hrasta lužnjaka golog korijena iznosi od 2,72 $\mathrm{g}$ do 18,94 $\mathrm{g}$ (Roth i dr., 2009).

Suha masa korijena u našem istraživanju (od 1,63 g do 4,10 g) manja je od mase zrako suhog korijena lužnjakovih sadnica starosti $1+0$ uzgojenih u gredici, tj. golog korijena, koja iznosi od 4,4 g do 5,8 g (Brekalo, 2005). Težina suhe tvari nadzemnog dijela, a posebno korijena, veća je u kontejnerima većeg volumena (Orešković i dr., 2006).

Omjer suhe mase nadzemnog dijela i suhe mase korijena važna je mjera preživljenja sadnica, a odnosi se na zonu transpiracije (lišće i izbojak) i zonu opskrbe vodom (korijenski sustav), (Jaenicke, 1999). Sama veličina sadnice nije toliko značajna ako ne postoji ravnoteža nadzemnog dijela sadnice i korijenskog sustava, odnosno velik izbojak zahtijeva i velik korijen koji će sadnicu opskrbljivati vodom i biljnim hranjivima.

Povoljan omjer masa stabljike : masa korijen, tj. onaj koji ukazuje na zdravu sadnicu je $1: 1$ do $1: 2$. (Jaenicke, 1999). Izmjereni su omjeri mase nadzemnog dijela i korijena od 0,13 (za klon 25) do 1,11 (za klon 53). Odnos biomase nadzemni dio / korijen u kontejnerima iznosi 0,3 za Paperpot i Bosnaplast 12, te 0,2 za Bosnaplast 18 (Ocvirek 1997).

Suha masa nadzemnog dijela čini od $11,50 \%$ (klon 25) do $52,55 \%$ (klon 53) cjelokupne suhe mase sadnice pa odnos postotnog učešća mase nadzemnog dijela i mase korijena u ukupnoj masi iznosi od 1:0,9 (klon 53), do 1:7,7 (klon 25). Kod jednogodišnjih biljaka hrasta lužnjaka (Quercus robur L.) uzgojenih u gredici taj odnos iznosi od $1: 3,0$ do $1: 3,2$, a suha masa nadzemnog dijela čini $24-25 \%$ ukupne mase sadnice (Brekalo, 2005).

Masa suhe tvari nadzemnog dijela i korijena lužnjakovih dvogodišnjih sadnica $(2+0)$ iznosi od $1: 1,3$ do $1: 2,1 \mathrm{u}$ korist korijenskog sustava (Roth, 1999).

Dobra razvijenost korijena odlučujući je preduvjet za dobar primitak na terenu (Ocvirek, 1997), jer što je manja transpiracijska, a veća apsorpcijska površina, bolji su uvjeti preživljenja sadnica nakon presadnje i bolji je inicijalni rast. Suha masa korijena, prepoznata je kao jedan od najvažnijih čimbenika koji utječu na opstanak i rast biljke nakon presadnje pa visoki omjer $\mathrm{S} / \mathrm{K}$ ne znači nužno i manji opstanak ako sadnice imaju dobro razvijen korijenski sustav.

U našem istraživanju ukupno je 24 uzoraka s omjerom suhe mase nadzemnog dijela sadnica i suhe mase korijenskog sustava 0,4 ili manjim, i možemo pretpostaviti da taj omjer definira kvalitetnu sadnicu. Uzorci koji potječu od klonova 3 i 21 imaju suhu masu korijena manju od 2,00 g i te sadnice vjerojatno ne bi imale dobar primitak na terenu nakon presadnje zbog male apsorpcijske površine. Ostali uzorci s povoljnim omjerom suhe mase nadzemnog dijela i suhe mase korijenskog sustava, imaju masu korijena veću od 2,0 g, što je jedan od preduvjeta za dobar opstanak i zadovoljavajući inicijalni rast sadnice nakon presadnje.
Sadnice s omjerom suhe mase nadzemnog dijela i suhe mase korijenskog sustava većim od 0,4 dobivene su od ukupno 25 klonova. Uzorci klonova 28, 31, 51 i 53 imaju suhu masu korijenskog sustava manju od 2,0 g, i uz nepovoljan omjer nadzemnog dijela sadnice i korjenskog sustava pretpostavljamo da će te sadnice imati loš primitak na terenu, slabo preživljenje i inicijalni rast, jer je transpiracijska površina velika, a zona apsorpcije mala. Posebno se ističu sadnice klona 53, koje imaju najnepovoljniji omjer suhe mase nadzemnog dijela i suhe mase korijenskog sustava $(1,11)$ i malu suhu masu korijenskog sustava (1,95 g).

\section{ZAKLJUČCI CONCLUSIONS}

U ovom istraživanju utvrđena je varijabilnost i morfološke razlike jednogodišnjih sadnica hrasta lužnjaka (Quercus robur L.) uzgojenih u kontroliranim uvjetima. Statističkom analizom utvrđeno je postojanje signifikantne razlike između aritmetičkih sredina uzoraka za parametre: suha masa lišća, stabljike, korijena, nadzemnog dijela sadnice i sveukupna suha masa. Varijabilnost dobivenih podataka za pojedine parametre dijelom je uvjetovana podrijetlom sjemenskog materijala, odnosno klonova hrasta lužnjaka (Quercus robur L.) koji potječu iz sedam gospodarskih jedinica s područja Uprave šuma Podružnice Bjelovar. Uzorci od 24 klona imaju povoljan omjer suhe mase nadzemnog dijela sadnice i korijenskog sustava, što ukazuje na dobar balans transpiracijske i apsorpcijske površine. Od svih 49 uzoraka, uzorci porijeklom od klonova 3, 21, 28, 31, 51 i 53 imaju suhu masu korijenskog sustava manju od 2,0 g, a uzorci klonova 28, 31, 51 i 53 imaju i nepovoljan omjer suhe mase nadzemnog dijela i korijenskog sustava, što upućuje na potencijalno slab primitak i preživljavanje sadnica tih klonova nakon presadnje.

\section{ZAHVALE}

\section{MENTIONS}

Za brižan rad sa sadnicama tijekom njihova uzgoja, od same sjetve pa do završnih izmjera, posebnu zahvalu upućujemo kolegama Matku Mužaru, mag. ing. silv., i Blaženki Molnar, mag. ing. silv.

Prof. dr. sc. Anamariji Jazbec, hvala na pomoći u statističkoj obradi prikupljenih podataka.

\section{LITERATURA}

\section{REFERENCES}

- Bobinec - Mikek, D., 2009: Utjecaj potencijala rasta korijena sadnica crnog bora (Pinus nigra F.J.Arnold) na njihovo preživljavanje. Magistarski rad. Šumarski fakultet Sveučilišta u Zagrebu, 180 str.

- Brekalo, Z., 2005: Utjecaj podrezivanja korijena na kvalitetu sadnica hrasta lužnjaka (Quercus robur L.). Magistarski rad. Šumarski fakultet Sveučilišta u Zagrebu, 120 str. 
- Drvodelić, D., M.Oršanić, S.Perić, M.Tijardović, 2013: Utjecaj navodnjavanja i mikroreljefa u rasadniku na morfološke značajke šumskih sadnica hrasta lužnjaka (Quercus robur L.) i kitnjaka (Quercus petraea (Matt.) Liebl). Šumarski list 9 - 10: 447-459.

- Duryea, M.L., 1984: Nursery Cultural Practices: Impacts on Seedling Quality. Pp 143-164.. In Duryea, M.L. and T.D. Landis (eds.). Forest Nursery Manual: Production of Bareroot Seedlings. Martinus Nijhoff/Dr. W.Junk. Publishers. Hague/Boston/ Lancaster. For Forest Research Laboratory, Oregon State University Corvallis 386p.

- Haase, D.L., 2007: Morphologycal and Physiological Evaluations of Seedling Quality. In:Riley, L.E.; Dumroes, R.K.; Landis, T.D., tech.coords. 2007. National proceedings: Forest and Conservation Nursery Associations-2006. Proc.RMRS-P-50. Fort Collins, CO:U.S. Department of Agriculture, Forest Service, Rocky Mountain Research Station.

- Hanson, P.J., Dickson, R.E., Isebrands, J.G., Crow, T.R., Dixon, R.K. 1986: A morphological indeks of Quercus seedling ontogeny for use in studies of physiology and growth. Tree Physiol. 2. 273-281 str.

- Jaenicke, H., 1999: Good Tree Nursery Practices - Practical Guidelines for Research Nurseries. International Centre for Reseach in Agroforestry. Nairobi, Kenya.

- Kajba, D., I.Katičić, I.Šumanovac, M.Žgela, 2009: Važnost klonskih sjemenskih plantaža u sjemenarstvu i očuvanju genofonda šumskih vrsta drveća u Hrvatskoj. Radovi Hrvatskog šumarskog instituta. 44 (1): 37-52.

- Katičić, I., 2012: Genetska raznolikost hrasta lužnjaka (Quercus robur L.) u klonskim sjemenskim plantažama u Hrvatskoj. Disertacija. Šumarski fakultet Sveučilišta u Zagrebu, 164 str.

- Matić, 1996: Uzgojni radovi na obnovi i njezi sastojina hrasta lužnjaka. Hrast lužnjak (Quercus robur, L.) u Hrvatskoj. Vinkovci - Zagreb: 167-212.

- Matić, S., S.Orlić, M.Harapin, 1996: Sjeme hrasta lužnjaka kao temeljni uvjet nastanka i opstanka lužnjakovih šuma. Hrast lužnjak (Quercus robur, L.) u Hrvatskoj. Vinkovci - Zagreb: 145157.

- Matić, S., N.Komlenović, S.Orlić, M.Oršanić, 1996: Rasadnička proizvodnja hrasta lužnjaka. Hrast lužnjak (Quercus robur, L.) u Hrvatskoj. Vinkovci - Zagreb, 159-166 str.
- Oršanić, M., S.Matić, I.Anić, 1996: Kontejnerska proizvodnja sadnica hrasta lužnjaka i njen utjecaj na kvalitetu šumskih kultura. Šumarski fakultet Sveučilišta u Zagrebu i Šumarski institut Jastrebarsko. Unapređenje proizvodnje biomase šumskih ekosustava. Knjiga 1. Zagreb: 307-312.

- Ocvirek 1997: Utjecaj termina sjetve na razvijenost biljaka hrasta lužnjaka (Quercus robur L.) u trima tipovima kontejnera. Jastrebarsko. Radovi šumarskog instituta 32(2): 55-72.

- Orešković, Ž., A.Dokuš, M.Harapin, T.Jakovljević, R.Maradin, 2006: Uzgoj sadnica hrasta lužnjaka (Quercus robur L.) i kitnjaka (Quercus petraea (Matt.) Liebl) u različitim tipovima kontejnera. Radovi Šumarski institut Jastrebarsko. Izvanredno izdanje 9: 75-86.

- Perić, S., 2001: Šumsko - uzgojna svojstva različitih provenijencija hrasta lužnjaka (Quercus robur, L.) u Hrvatskoj. Disertacija. Šumarski fakultet Sveučilišta u Zagrebu, 169 str.

- Ritchie, G.A., 1984.: Assesing seedling quality. Pp. 243-259. In Duryea, M.L. and T.D. Landis (eds.). Forest Nursery Manual: Production of Bareroot Seedlings. Martinus Nijhoff/Dr. W.Junk. Publishers. Hague/Boston/Lancaster. 386p.

- Roth, V., 1999.:Neka svojstva sjemena i sadnica hrasta lužnjaka (Quercus robur, L.) iz različitih sjemenskih zona i rajona Hrvatske. Magistarski rad. Šumarski fakultet Sveučilišta u Zagrebu, 91 str.

- Roth, V., T.Dubravac, I.Pilaš, S.Dekanić, Z.Brekalo, 2009: Krupnoća žira hrasta lužnjaka (Quercus robur L.) i kitnjaka (Quercus petraea Liebl.) kao čimbenik rasta i razvoja sadnica. Šumarski list 133(5-6):257-266.

- Saračević, S., 2002: Kvantitativne i kvalitativne osobine žira hrasta lužnjaka (Quercus robur L.) u sastojinama sliva rijeke Česme. Magistarski rad. Šumarski fakultet Sveučilišta u Zagrebu, 116 str.

- Sever, K., 2012: Utjecaj ekofizioloških čimbenika na razvoj rasplodnih organa hrasta lužnjaka (Quercus robur, L.). Disertacija. Šumarski fakultet Sveučilišta u Zagrebu, 134 str.

- Vidaković, M., 1996: Oplemenjivanje hrasta lužnjaka u Hrvatskoj. Hrast lužnjak (Quercus robur, L.) u Hrvatskoj. Vinkovci - Zagreb: 95-111.

- Pravilnik o provenijencijama svojti šumskog drveća. Narodne novine br. 147 /2011, 96/2012, 115/2014, 114/2015.

- Šumsko - gospodarska osnova područja, 2016-2025

\section{SUMMARY}

Forests of the pedunculate oak (Quercus robur L.) management class in the Republic of Croatia cover an area of approximately 200,000 ha. In view of the size of the distribution range, the total growing stock amounting to over 48 million $\mathrm{m}^{3}$, the annual current increment of 1 million $\mathrm{m}^{3}$ and morphological differentiation, the study of pedunculate provenances is of exceptional importance. Clonal seed orchards were established with the purpose of achieving frequent yields, obtaining genetically valuable seed material and preserving the genetic variability, which lessens the possibility of local population disappearance caused by changed environmental conditions or the occurrence of new diseases and pests. Samples of seed material with a total of 49 different clones were collected from the 2015 yield in the „Plešćice“ clonal seed orchard of pedunculate oak (Quercus robur L.) and one-year-old container seedlings were grown under controlled conditions. Dry mass content of leaves, stems and roots was measured in the samples containing 5 seedlings of each clone. Their morphological differences and variability were determined and the clones whose seedlings showed poor potential for the use in biological forest regeneration were defined. Mean dry mass of roots lower than $2.0 \mathrm{~g}$ was found in the samples of 6 clones, while 4 of them showed an unfavourable ratio of dry matter of the aboveground part and dry matter of the root system, leading to the assumption that the seedlings of these samples might have potentially poor reception in the field, poor survival and initial growth.

KEY WORDS: Clonal seed orchard, seedlings, containers, dry biomass of seedlings, variability. 